\title{
Isolasi dan Identifikasi Streptococcus sp. dari Sapi Perah Penderita Mastitis Subklinis di Purwoharjo Banyuwangi
}

\section{Isolation and Identification Streptococcus sp. from Dairy Cattle with Subclinical Mastitis in Purwoharjo Banyuwangi}

\author{
Adinda Dilla Pribadi ${ }^{*}$, Aditya Yudhana ${ }^{2}$, Sri Chusniati ${ }^{3}$ \\ ${ }^{1}$ Bachelor of Veterinary Medicine, ${ }^{2}$ Department of Parasitology, ${ }^{3}$ Department of Microbiology, \\ Faculty of Veterinary Medicine, Airlangga University, \\ UNAIR C-Campus Mulyorejo, Surabaya, Jawa Timur, Indonesia, 60115 \\ *Corresponding author: adinda.dilla.pribadi-2015@ fkh.unair.ac.id
}

\begin{abstract}
Abstrak
Mastitis subklinis adalah radang pada ambing yang tidak menunjukkan gejala klinis dan dapat menurunkan produksi susu. Streptococcus $s p$. adalah salah satu mikroorganisme patogen yang dapat menyebabkan mastitis subklinis pada sapi perah. Tujuan dari penelitian ini adalah untuk mendeteksi Streptococcus sp. pada susu sapi perah. Sebanyak 26 ekor sampel sapi perah dilakukan deteksi mastitis subklinis menggunakan Uji California Mastitis Test (CMT) di Purwoharjo, Banyuwangi. Isolasi dan identifikasi bakteri dilakukan dengan menggunakan kultur agar, pewarnaan Gram, dan uji biokimia. Hasil penelitian menunjukkan bahwa bakteri Streptococcus sp. terdeteksi pada 5 (19.23\%) ekor sampel di Purwoharjo Banyuwangi.
\end{abstract}

Kata kunci: sapi perah, mastitis subklinis, Streptococcus sp., Purwoharjo, Banyuwangi

\section{Abstract}

Subclinical Mastitis is an inflammation of the mammary gland which frequently found asymptomatic, and can decrease milk production. Streptococcus sp. is one of the pathogenic microorganism agent that can cause subclinical mastitis in dairy cattle. The aim of this study was to detect Streptococcus sp. bacteria in dairy cattle milk product. A total of 26 samples obtained from dairy cattle which positively detected subclinical mastitis using California Mastitis Test (CMT) in Purwoharjo, Banyuwangi. Bacterial isolation and identification was performed using agar culture, Gram staining, and biochemical test. The results showed that Streptococcus sp. bacteria were detected from 5 (19.23\%) samples in Purwoharjo, Banyuwangi.

Key words: dairy cattle, subclinical mastitis, Streptococcus sp., Purwoharjo, Banyuwangi

\section{PENDAHULUAN}

Susu sapi perah merupakan salah satu bahan pangan yang sangat penting untuk mencukupi kebutuhan masyarakat. Kebutuhan susu pertahun bertambah seiring dengan kesadaran masyarakat untuk pemenuhan protein (Utomo dan Miranti, 2010). Kebutuhan susu dalam negeri hanya dapat terpenuhi sekitar $23.73 \%$. Hal ini menunjukkan bahwa masih rendahnya penyediaan produksi susu segar nasional disebabkan karena produktivitas ternak yang rendah dan juga populasi ternak yang sedikit (Nurtini dan Anggriani, 2014).
Upaya untuk memenuhi kebutuhan susu segar, dilakukan peningkatan produksi susu dengan pengembangan peternakan sapi perah. Salah satu daerah yang mendukung pengembangan peternakan sapi perah adalah Kabupaten Banyuwangi (Masruroh, 2017). Kabupaten Banyuwangi memiliki beberapa wilayah pengembangan sapi perah salah satunya berada di Kecamatan Purwoharjo. Tercatat populasi sapi perah betina produktif di Kecamatan Purwoharjo Kabupaten Banyuwangi sebanyak 169 ekor (Dinas Pertanian Kab. Banyuwangi, 2018). 
Usaha pengembangan peternakan sapi perah tidak luput dari munculnya beberapa penyakit. Salah satu penyakit yang sering terjadi pada peternakan sapi perah adalah mastitis. Mastitis merupakan penyakit peradangan pada ambing yang sangat merugikan (Vliegher et al., 2012). Penyakit mastitis terbagi menjadi dua jenis yaitu mastitis klinis dan subklinis (Tuasikal dkk., 2012). Sudarwanto dan Sudarnika (2008) menyebutkan bahwa persentase mastitis subklinis mencapai $97-98 \%$ dan $2-3 \%$ merupakan mastitis klinis yang mudah terdeteksi karena mastitis klinis menunjukkan gejala yang tampak pada kondisi fisik ambing.

Mastitis subklinis merupakan peradangan pada ambing yang tidak menunjukkan gejala klinis dan terjadi sebelum mastitis klinis. Hal ini terkadang tidak disadari oleh peternak karena sapi perah terlihat dalam keadaan sehat tetapi produksi susu yang dihasilkan menurun dan dapat menjadi reservoir mikroorganisme yang akan menginfeksi sapi perah lain yang berdekatan dengan sapi perah terinfeksi (Herlina dkk., 2015). Kejadian mastitis subklinis di Indonesia mengakibatkan penurunan produksi susu sampai $25 \%$ dari total produksi susu (Departemen Pertanian, 2004 dalam Adriani, 2010). Selain menyebabkan penurunan produksi susu, mastitis subklinis juga dapat menyebabkan penurunan kualitas susu, biaya perawatan dan pengobatan yang mahal, pengafkiran ternak lebih awal serta pembelian sapi perah baru (Morin dan Hurley, 2003 dalam Effendi, 2008).

Streptococcus sp. dan E. coli merupakan salah satu bakteri patogen yang merugikan peternak karena dapat menyebabkan penurunan kualitas dan produksi susu sekitar 10-20\% (Pradika dkk., 2019). Streptococcus sp. yang terdapat dalam ambing membuat jumlah sel somatik (JSS) bertambah sehingga apabila selsel somatik tersebut runtuh akan membuat kualitas susu menjadi buruk (Forsmasn et al., 1997). Streptococcus sp. yang terdapat pada susu juga dapat menimbulkan masalah kesehatan masyarakat seperti septikemia dan meningitis pada bayi jika susu tersebut dikonsumsi (Andersen et al., 2007).Oleh karena itu, perlu dilakukan penelitian dengan tujuan untuk mengetahui keberadaan Streptococcus sp. pada sapi perah yang terindikasi mastitis subklinis di Kecamatan Purwoharjo Kabupaten Banyuwangi melalui isolasi dan identifikasi guna membatasi penyebaran mastitis subklinis dan melakukan pengobatan pada sapi perah yang terindikasi mastitis subklinis akibat Streptococcus $s p$.

\section{METODE PENELITIAN}

\section{Pengambilan Sampel}

Pengambilan sampel sapi perah ditentukan dengan menggunakan kriteria yaitu kondisi kandang sapi perah yang kurang bersih. Sapi perah dipilih sebanyak 26 ekor untuk dilakukan Uji California Mastitis Test (CMT). Besar sampel sapi perah ditentukan dengan menggunakan rumus deteksi penyakit pada suatu populasi di daerah bebas (Martin dkk., 1987 dalam Rahayu, 2015).

$$
\begin{gathered}
\mathrm{n}=\left[1-(1-\mathrm{a})^{1 / \mathrm{D}}\right][\mathrm{N}-(\mathrm{D}-1) / 2] \\
\mathrm{n}=25,76(26 \text { ekor })
\end{gathered}
$$

Keterangan:

n: besar sampel

a: tingkat konfidensi, besarnya $95 \%$ atau $99 \%$

$\mathrm{N}$ : populasi

D: jumlah hewan sakit dalam populasi, jika tidak diketahui digunakan asumsi $10 \%$

\section{Uji California Mastitis Test (CMT)}

Uji CMT dilakukan dengan menambahkan 2 $\mathrm{ml}$ susu dari masing-masing puting ke paddle kemudian ditambahkan $2 \mathrm{ml}$ reagen CMT. Setelah itu di goyang-goyangkan selama 10-15 detik sampai homogen. Hasil reaksi brenilai 0-4 dimana 0 tidak terjadi reaksi sedangkan 4 terjadi pembentukan gel (Suryowardojo, 2012).

\section{Isolasi bakteri dengan Blood Agar (BA)}

Sebanyak satu mata ose susu sapi perah digoreskan pada permukaan media Blood Agar (BA) secara aseptis. Kemudian di inkubasi pada suhu $37^{\circ} \mathrm{C}$ selama 24 jam (Sugiri dan Anri, 2010).

\section{Identifikasi dengan Pewarnaan Gram}

Fiksasi preparat dengan menggunakan Bunsen. Kemudian preparat ditetesi dengan 
kristal violet selama 2 menit. Bilas dengan air mengalir dan tetesi lagi dengan larutan lugol selama 1 menit. Lunturkan dengan alkohol 95\% selama 10-30 detik. Alkohol dibilas menggunakan air mengalir dan tambahkan zat warna safranin selama 2 menit. Bilas dengan air mengalir. Preparat dikeringkan untuk mengamati morfologi sel menggunakan mikroskop binokuler dengan perbesaran 1000 kali (Handijatno dkk., 2016).

\section{Identifikasi dengan Uji Katalase}

Koloni yang diduga Streptococcus sp. diambil menggunakan ose steril kemudian digoreskan pada gelas objek yang sudah ditetesi hidrogen peroksida $\left(\mathrm{H}_{2} \mathrm{O}_{2}\right) 3 \%$. Streptococcuss sp akan menunjukkan hasil negatif yaitu tidak terjadi pembentukan gelembung-gelembung (Rahayu, 2015).

\section{Analis is Data}

Data yang didapatkan akan ditabulasi dan ditampilkan dalam tabel.

\section{HASIL DAN PEMBAHASAN}

Mastitis merupakan salah satu penyakit infeksius yang sebagian besar dapat dijumpai pada peternakan sapi perah (Quinn et al., 2002). Mastitis disebabkan masuknya mikroba ke dalam ambing melalui lubang puting yang melebar dan menyebabkan keradangan (Garcia, 2004).

Berdasarkan hasil Uji California Mastitis Test (CMT) yang dilakukan terhadap 26 ekor sapi perah didapatkan sebanyak $23(88.46 \%)$ ekor positif mastitis subklinis (Tabel 1). Hasil penelitian Effendi (2008) juga menunjukkan bahwa prevalensi mastitis subklinis di Jawa Timur diperkirakan berkisar $80-86 \%$. Menurut Poeloengan (2009) sebagian besar penyakit yang menyerang sapi perah di Indonesia adalah mastitis subklinis dan kejadian penyakit mastitis di Indonesia mencapai $85 \%$.

Kejadian mastitis subklinis di Kecamatan Purwoharjo Kabupaten Banyuwangi kemungkinan besar disebabkan oleh manajemen kelola peternakan yang kurang memadai seperti buruknya higienitas pemerahan dan sanitasi kandang. Hal tersebut didukung oleh Surjowardojo (2014) menyatakan bahwa faktorfaktor seperti sanitasi lingkungan yang buruk dan higienitas pada saat pemerahan berperan penting pada kejadian mastitis subklinis di peternakan sapi perah. Nurhayati dan Martindah (2015) juga menambahkan kejadian mastitis subklinis di Indonesia sangat tinggi karena pengelolaan peternakan yang kurang baik. Kejadian mastitis subklinis di Kecamatan Purwoharjo Kabupaten juga disebabkan oleh pemerah karena hampir semua pemerah tidak melalukan teat dipping sesudah pemerahan selesai.

Menurut Kurniawan dkk., (2014) hygiene saat pemerahan seperti teat dipping setelah pemerahan perlu dilakukan dengan tujuan menekan jumlah cemaran bakteri yang dapat masuk ke dalam ambing dan mencemari susu. Hasil penelitian Sutarti dkk., (2003) juga menyebutkan bahwa kebersihan sapi setelah pemerahan akan memperkecil kemungkinan kejadian mastitis. Penyebab lain mastitis subklinis pada penelitian ini adalah lingkungan yang kotor seperti tempat pembuangan feses yang dekat dengan kandang. Usmiati dan Abubakar (2009) menyatakan bahwa feses merupakan sumber kontaminasi mikroba yang juga dapat menyebabkan mastitis subklinis.

Berdasarkan isolasi dan identifikasi diperoleh hasil 5 ekor (19.23\%) sampel positif mastitis subklinis terdapat Streptococcus $s p$. Streptococcus $s p$. ditemukan pada susu positif mastitis subklinis dari 5 ekor sapi perah yang berasal dari 16 kwartir (Gambar 1). Menurut Vliegher et al. (2012), mastitis subklinis pada sapi perah sering terjadi akibat infeksi dari genus Streptococcus $s p$. yang terdiri dari beberapa spesies yaitu Streptococcus agalactiae, Streptococcus dysagalactiae dan Streptococcus uberis. Streptococcus sp. berperan sebagai sumber infeksi bakteri karena membentuk koloni pada puting dan sering menghasilkan respon keradangan yang dapat diukur dengan peningkatan Jumlah Sel Somatik (JSS).

Menurut Filev (1977), spesies Streptococcus $s p$. penyebab mastitis subklinis memiliki zona hemolisis- $\beta$ atau Group-B Streptococcus (GBS) 
Tabel 1. Hasil pemeriksaan mastitis subklinis dengan Uji California Mastitis Test (CMT)

\begin{tabular}{ccccc}
\hline Nama Desa & $\begin{array}{c}\text { Jumlah } \\
\text { sampel (ekor) }\end{array}$ & $\begin{array}{c}\text { Jumlah kuartir } \\
\text { yang diuji CMT } \\
\text { (kuartir) }\end{array}$ & $\begin{array}{c}\text { Jumlah kuartir } \\
\text { positif CMT } \\
\text { (kuartir) }\end{array}$ & $\begin{array}{c}\text { Jumlah penderita } \\
\text { mastitis subklinis } \\
\text { (ekor) }\end{array}$ \\
\hline Glagahagung & 16 & 64 & 39 & 15 \\
Wringinpitu & 10 & 40 & 18 & 8 \\
\hline Jumlah & 26 & 104 & $57(54.80 \%)$ & $23(88.46 \%)$ \\
\hline
\end{tabular}

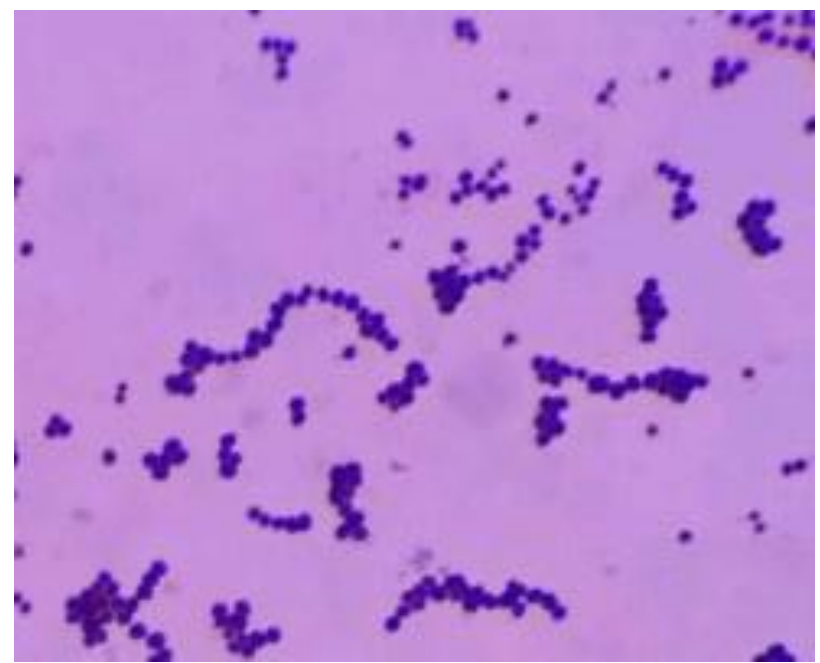

Gambar 1. Hasil pewarnaan gram menunjukkan gram positif Streptococcus sp. perbesaran $100 \mu \mathrm{m}$

adalah Streptococcus agalactiae sedangkan yang memiliki zona hemolisis- $\alpha$ adalah Streptococcus uberis dan Streptococcus dysagalactiae.

S. agalactiae merupakan spesies dari Streptococcus yang menjadi penyebab utama penyakit mastitis subklinis. S. agalactiae termasuk kedalam salah satu bakteri yang menyebabkan infeksi tipe persisten tingkat rendah tetapi tidak memiliki tingkat kesembuhan sendiri yang sangat tinggi. Selain itu, bakteri ini juga memiliki peran penting untuk menimbulkan kerugian diantaranya yaitu mengurangi jumlah produksi susu, nilai gizi susu berkurang, umur simpan produk susu cair menurun karena augmentasi pertumbuhan bakteri pembusuk serta menurunkan kualitas keju dan produk olahan lainnya (Keefe, 1997). S. dysagalactiae dan $S$. uberis disebut sebagai bakteri patogen lingkungan. Spesies ini dikenal memiliki kemampuan bertahan hidup dan berkembang biak yang ekstrim. Karakteristik dari bakteri patogen lingkungan adalah memungkinkan adanya penularan ketika pemerah kontak langsung dengan puting sapi perah (Mirjana, et al., 2018). Penelitian Zadocks et al., (2001) menjelaskan bahwa S.uberis dapat ditularkan dari puting ke puting sapi perah melalui teat cup liners mesin pemerah susu. Oleh karena itu celup puting menggunakan sangat diperlukan setelah proses pemerahan susu.

\section{KESIMPULAN}

Dapat disimpulkan bahwa terdapat Streptococcus sp. pada susu sapi perah yang terindikasi mastitis subklinis di Purwoharjo, Banyuwangi dengan tingkat kejadian sebesar $19.23 \%$.

\section{UCAPAN TERIMA KASIH}

Peneliti mengucapkan terimakasih kepada Fakultas Kedokteran Hewan Universitas Airlangga, atas diperbolehkannya penelitian di laboratorium. Peneliti juga mengucapkan terimakasih kepada Dinas Pertanian dan Penanaman Modal dan Pelayanan Terpadu Satu Pintu Kabupaten Banyuwangi, atas kesediannya untuk dilakukan pengambilan sampel pada daerah tersebut. 


\section{DAFTAR PUSTAKA}

Adriani. 2010. Panggunaan Somatik Cell Count (SCC), Jumlah Bakteri dan California Mastitis Test (CMT) untuk Deteksi Mastitis pada Kambing. J. Ilmiah Ilmu-Ilmu Peternakan, 8(5), 230.

Andersen, J., Christensen, R., Hertel, J. 2007. Clinical Features and Epidemiology of Septicaemia and Meningitis in Neonates Due to Streptococcus in Copenhagen Country. Acta Paediatrika, 93(10).

Dinas Pertanian Kabupaten Banyuwangi. 2018. Populasi Ternak Per Wilayah (ekor). Dinas Pertanian Kabupaten Banyuwangi. Banyuwangi.

Effendi, M.H. 2008. Angka Prevalensi Bovine Mastitis dari Beberapa Peternakan Sapi Perah di Jawa Timur. Fakultas Kedokteran Hewan. Universitas Airlangga.

Filev, F. 1997. Occurrence and Etiology for Subclinical Mastitis in Cows. J. Veterinarnomeditsinski Nauki, 14(1), 74.

Garcia, A. 2004. Contagious vs. Environmental Mastitis. Extension Extra Dairy Science. South Dakota State University. USA. p 4.

Handijatno, D., Tyasningsih, W., Narumi, H.E., Sarudji, S., Chusniati, S. 2016. Penuntun Praktikum Mikrobiologi Veteriner I Program S-1. Universitas Airlangga. Hal 9-10.

Herlina, N., Afiati F., Cahyo A.D., Herdiyani P. D., Qurotunnada, Tappa, B. 2015. Isolasi dan Identifikasi Staphylococcus aureus dari Susu Mastitis Subklinis di Tasikmalaya, Jawa Barat. Pros Sem Nas Masy Biodiv Indonesia, 1(3), 414.

Kurniawan, I., Sarwiyono, Surjowardojo. P. 2014. Pengaruh Teat Dipping Menggunakan Dekok Daun kersen (Muntingia calabura L.) terhadap Tingkat Kejadian Mastitis. J. IlmuIlmu Peternakan, 23(3), 27.

Masruroh, S. 2017. Analisis Kelayakan Finansial Usaha Peternakan Sapi Perah di Kecamatan Purwoharjo Kabupaten Banyuwangi [Skripsi]. Fakultas Pertanian. Universitas Jember. Hal 4.

Mirjana, Z., Katarina G., Tanja D., Ljiljana R. 2018. In Vitro Evaluation Antimicrobial Potential of Streptococcus uberis Isolated from a Local Cheese from Shoutheastern Serbia. Departemen of Biology and Ecology Faculty of Science. University of Kragujevac. p 521.

Nurhayati, I.S., Martindah, E. 2015. Pengendalian Mastitis Subklinis melalui Pemberian Antibiotik Saat Periode Kering pada Sapi Perah. Wartazoa, 25(2), 074.

Nurtini, S., Anggriani, M. 2014. Profil Peternakan Sapi Perah Rakyat di Indonesia. Gadjah Mada University Press. Yogyakarta. Hal 16.

Poeloengan, M. 2009. Aktivitas Air Perasan dan Ekstrak Etanol Daun Encok terhadap Bakteri yang Diisoasi dari Sapi Mastitis Subklinis. Dalam: Seminar Nasional Teknologi Peternakan dan Veteriner 2009. Balai Besar Penelitian Veteriner. Bogor. Hal 300.

Pradika, A.Y., Chusniati, S., Purnama, M.T.E., Effendi, M.H., Yudhana, A., Wibawati, P.A. 2019. Uji Total Escherichia coli pada Susu Sapi Segar di Koperasi Peternak Sapi Perah (KPSP) Karyo Ngremboko Kecamatan Purwoharjo Kabupaten Banyuwangi. J. Med. Vet., 2(1), 1-6.

Quinn, P.J., Markey, B.K., Carter, M.E., Donelly, W.J., Leonard, F.C. 2002. Veterinary Microbiology and Microbial Disease. Blackwell Publishing. USA. p 465. 
Rahayu, S. 2015. Deteksi Streptococcus agalactiae Penyebab Mastitis Subklinis pada Sapi Perah di Kecamatan Cendana Kabupaten Enrekang [Skripsi]. Fakultas Kedokteran Hewan. Universitas Hasanuddin. Hal 11-14.

Sudarwanto, M., Sudarnika, E. 2008. Nilai Diagnostik Tes IPB Mastitis Dibandingkan dengan Jumlah Sel Somatik dalam Susu. Departemen Ilmu Penyakit Hewan dan Kesehatan Masyarakat Veteriner Fakultas Kedokteran Hewan. Fakultas Kedokteran Hewan.

Sugiri, Y.D., Anri, A. 2010. Prevalensi Patogen Penyebab Mastitis Subklinis (Staphylococcus aureus dan Streptococcus agalactiae) dan Patogen Penyebab Mastitis Subklinik Lainnya pada Peternak Skala Kecil dan Menengah di Beberapa Sentra Peternakan Sapi Perah di Pulau Jawa.

Suryowardojo, P. 2012. Penampilan Kandungan Protein dan Kadar Lemak Susu pada Sapi Perah Mastitis Friesian Holstein. Fakultas Peternakan. Universitas Brawijaya, 2(1), 44.

Surjowardojo, P. 2014. Tingkat Kejadian Mastitis dengan Whiteside Test dan Produksi Susu Sapi Perah Friesien Holstein. Fakultas Peternakan. J. Ternak Trop., 12(1), 50-51.
Sutarti, E., Budiharta, S., Sumiarto, B. 2003. Prevalensi dan Faktor-Faktor Penyebab Mastitis pada Sapi Perah Rakyat di Kabupaten Semarang Propinsi Jawa Tengah. J. Sain Vet., 21(1), 48.

Usmiati, S., Abubakar. 2009. Teknologi Pengolahan Susu. Balai Besar Penelitian dan Pengembangan Pascapanen Pertanian. Bogor.

Utomo, B., Miranti, D.P. 2010. Tampilan Produksi Susu Sapi Perah yang Mendapatkan Perbaikan Manajemen Pemeliharaan. Balai Pengkajian Teknologi Pertanian Jawa Tengah, 25(1), 22.

Vliegher, S.D., Fox, L.K., Piepers, S., McDougall, S., Barkemas, H.S. 2012. Invited Review: Mastitis in Dairy Heifers: Nature of the Disease, Potential Impact, Prevention, and Control. J. Dairy Sci., 95(3), 1028.

Zadoks, R.N., Allore, H.G., Barkema, H.W., Sampimon, O.C., Grohn, Y.T., Schukken Y.H. 2001. Analysis of an Outbreak of Streptococcus uberis Mastitis. J. Dairy Sci., 84(3), 592. 